\title{
Spatial differences of aeolian desertification responses to climate in arid Asia
}

\author{
Xunming Wang a, b, Ting Hua ${ }^{\text {a, }}{ }^{*}$, Lili Lang ${ }^{\text {a }}$, Wenyong Ma ${ }^{a}$ \\ ${ }^{a}$ Key Laboratory of Water Cycle \& Related Land Surface Processes, Institute of Geographic Sciences and Natural \\ Resources Research, Chinese Academy of Sciences, Beijing, China \\ ${ }^{\mathrm{b}}$ Key Laboratory of Desert and Desertification, Cold and Arid Regions Environmental and Engineering Research \\ Institute, Chinese Academy of Sciences, Lanzhou, China
}

\section{ABSTRACT}

Most areas of arid Asia are covered by aeolian dunes, sand sheets, gravels, and desert steppes, and may jeopardize nearly 350 million people if climate change increases aeolian desertification. Although the aeolian desertification is mainly triggered by climate changes are extensively acknowledged, the responses of aeolian desertification to various climate scenarios are poorly understood. Based on the tight combinations of dune activity index (DAI) trends and of aeolian desertification, here the spatial differences of aeolian desertification responses on various climate scenarios were reported. The analyzed results show that the variations in temperature, precipitation and wind regime have no significant contributions on aeolian desertification in the extremely arid Asia. From the early to blooming periods of vegetation growth, although temperature rise may benefit vegetation growths in some high latitudes and altitudes, the temperature rise may increase aeolian desertification in most arid Asia regions such as Mongolia, West and Central Asia. In arid Asia, although precipitation increases may benefit the rehabilitation, decreases in precipitation is not the key role on aeolian desertification occurrences in extremely arid regions. From the early to blooming periods of vegetation growths, spatial trends of the sensitivity of aeolian desertification to wind regime varied. Generally, at the regional scales there are relative high sensitivities for aeolian desertification to climate changes in the eastern and western regions of arid Asia, and the climate changes may not play important roles on aeolian desertification occurrence in the central regions. The spatial differences of aeolian desertification responses on climate changes indicate various strategies for aeolian desertification combating are needed in different regions of arid Asia. Keywords: aeolian desertification; climate scenario; response; arid Asia

\footnotetext{
*Corresponding author.

E-mail address: hactgexin@1zb.ac.cn (T. Hua)
} 


\section{Introduction}

Aeolian desertification mainly occurs when arable land and grassland are degraded to such a degree that aeolian transport is exacerbated by decreases in vegetation cover or increases in the intensity of aeolian processes (Martínez-Graña et al., 2015), and when anchored or semi-anchored dunes are reactivated (Wang et al., 2013), is the dominant forms of land degradation in arid regions. Arid Asia covers areas about $1.5 \times 10^{8} \mathrm{~km}^{2}$, stretch from Northeast Asia to Central and West Asia, with annual precipitation of $<500 \mathrm{~mm}$ (Fig. 1) of which more than $70 \%$ is covered by aeolian sand dunes, sand sheets, gravel surfaces, and steppes with high risks of aeolian desertification (UNEP 1992). At present these areas are being managed as traditional pastoral and agricultural systems that with aeolian desertification occurrence could be seriously endangered, jeopardizing the existence of nearly 350 million people (Fig. S1). In arid Asia and in the other regions of the world, the aeolian desertification can be indicated by variations in the dune activity index (DAI, Thomas et al., 2005; Wang et al., 2008, 2009).

DAI is a parameter synthesized multi climate scenarios including moisture, thermal, and wind regimes (e.g., Ash and Wasson, 1983; Talbot, 1984; Tsoar, 2005; Yizhaq et al., 2007, 2009; Yehonathan et al., 2013). Besides the uncertainties of effects of temperature variations, decreases in precipitation, and increases in wind velocity may result in increases of DAI, and consequently, trigger aeolian desertification in the region. Although the variations in DAI and aeolian desertification occurrence are affected by complicated factors and multi climate scenarios, at the global scales there were spatial differences for the responses of aeolian desertification to various climate scenarios. For instances, Wang et al $(2007,2008)$ suggested that the wind regime is one of the key factors on controlling aeolian desertification in China, while Conway and Schipper (2011) 
considered that low precipitation occurred in the 1960s to 1980 s were the main causes of aeolian desertification in Africa, and McConnell et al. (2007) suggested that temperature rise cause the extensive aeolian desertification occurrence in arid zones of South America. However, although dune activity and aeolian desertification trends in the near future in other arid zones of the world have been discussed and predicted (e.g., Knight et al., 2004; Thomas et al., 2005), at present, the responses of aeolian desertification to the various climate scenarios and the spatial differences of major controls on aeolian desertification in the arid Asia is still poorly understood.

At present, at large scales the remote-sensing products and its derived databases provided abundant resources to analyze the regional vegetation and environmental changes (e.g., Hansen et al., 2010; Fensholt and Proud, 2012). Among these derived databases the third generation of the normalized difference vegetation index (NDVI-3g) represent changes in the vigor and photosynthetic capacity (or greenness) of vegetation canopy (Chen and Brutsaert, 1998; Fang and Piao, 2003), whose values are positively correlated with the aeolian desertification status of the region (e.g., Becker and Choudhury, 1988; Piao et al., 2005; Helldén and Tottrup, 2008). Therefore, in the present study, combined the DAI, the different climate scenarios and the NDVI3g data bases, the spatial differences of responses of aeolian desertification to various climate scenarios, and the key climate scenarios on controlling the aeolian desertification were examined, which provided the fundamentals for the aeolian desertification combating in the arid Asia.

\section{Data sources and Methods}

The satellite-derived third generation of the NDVI database is widely employed as a surrogate to detect climate-induced changes in vegetation activity (Tucker et al., 2005; Pinzon et 
al., 2014) and desertification (Oba et al., 2001; Herrmann and Tappan, 2013).The biweekly Global Inventory Modeling and Mapping Studies (GIMMS) NDVI-3g dataset with a spatial $1 / 12^{\circ} \times 1 / 12^{\circ}$ resolution available from 1982 to 2013 was derived from the Advanced Very High Resolution Radiometer (AVHRR) sensor, and was corrected for calibration, view geometry, volcanic aerosols, and other factors not related to the actual vegetation change (Tucker et al., 2005). Based on the Maximum Value Compositing (MVC) technique (Holben, 1986), the highest NDVI value of a 15-day period was extracted to represent the value for each biweekly interval. In the present study, although low NDVI pixels (i.e., < 0.1) in regions with very sparse vegetation might decrease resolutions of the analyzed results (e.g., Piao et al., 2011; Zhang et al., 2013; Shen et al., 2015), after considering the surface characteristics of arid Asia those pixels with low NDVI $(<0.1)$ were still maintained in our analysis processes as previous studies suggested (Tucker et al., 1991; Montandon and Small, 2008).

All climate variables involved in the DAI processing (i.e., air temperature, precipitation, and wind velocity) was obtained from the Princeton Climate Database (Sheffield et al., 2006), which is constructed by combining global observation-based databases with the National Centers for Environmental Prediction-National Center for Atmospheric Research (NCEP-NCAR) being corrected by four reanalysis datasets, including the Climatic Research Unit (CRU), the Global Precipitation Climatology Project (GPCP), the Tropical Rainfall Measuring Mission (TRMM), and National Aeronautics and Space Administration (NASA). Both the temperature and precipitation data was scaled to match the CRU IS3.0 monthly dataset. Although this database available contains multiple temporal (3-hourly, daily, and monthly) and spatial resolutions $\left(0.25 \times 0.25^{\circ}, 0.5\right.$ $\times 0.5^{\circ}$, and $1 \times 1^{\circ}$ ) from 1948 to 2008 , here only the monthly dataset with $0.5 \times 0.5^{\circ}$ spatial 
resolutions were employed. In addition, before the further analysis were carried out the raw precipitation $\left(\mathrm{kg} \cdot \mathrm{m}^{-2} \cdot \mathrm{s}^{-1}\right)$ and temperature $(\mathrm{K})$ data were converted into those with units of $\mathrm{mm}$ and ${ }^{\circ} \mathrm{C}$, respectively, to meet the DAI processing.

Lancaster's (1988) DAI were employed because it has been successfully applied to determine dune activity and aeolian desertification trends over the historical periods and in the near future in some regions of arid Asia (e.g., Wang et al., 2004, 2005, 2006, 2007, 2009) and in the other regions of the global (e.g., Muhs and Maat, 1993; Bullard et al., 1997; Lancaster and Helm, 2000; Thomas and Leason, 2005). Lancaster's indices $(M)$ is generated as follows:

$$
M=W /\left(P_{M} / P_{E}\right)
$$

where $W$ is the percentage of the time that the wind is above the threshold for sand transport and $P$ represents water-related parameters $\left(P_{M}\right.$ for precipitation and $P_{E}$ for evapotranspiration). In the present study, $W$ was replaced with $U^{3}$, as this approach has been successfully employed for other DAI (e.g., Talbot, 1984; Wang et al., 2009) and in other wind erosion models (e.g., Shao, 2008) to account for data outputs. $P_{M}$ is obtained by averaging the precipitation in the previous and the current month (i.e., $P_{M}=\left(P_{-1}+P_{0}\right) / 2$ ), and $P_{E}$ is the potential evapotranspiration generated using the temperature-based method of Thornthwaite (1948), which accounts for the effects of month and latitude.

The Pearson's correlation coefficients of each pixel were employed to illustrate the relationships between NDVI and DAI and climate parameters (temperature, precipitation, and wind regime). Due to some data missing for some years in the southwestern arid Asia, the correlation coefficients cannot be compared directly among pixels because of their different degrees of freedom, and therefore, the significance levels of correlation were mapped. Due to the 
differences of spatial resolutions, the NDVI dataset (with resolutions $1 / 12 \times 1 / 12^{\circ}$ ) was resampled into spatial resolutions of $0.5^{\circ} \times 0.5^{\circ}$ to keep in accordance with that of climate dataset. In addition, because during the growing seasons there were relative high vegetation activity in arid Asia, and in order to acquire the analyzed results with more precise here aeolian desertification responses during the early (May and June) and blooming (July and August) periods of vegetation growths to DAI and various climate scenarios were mainly discussed. All calculations and analyses were performed during the overlapped period of 1982-2008 of the NDVI and climate datasets.

\section{Results and discussion}

\subsection{Relations between the DAI and the NDVI}

The spatial trends of NDVI during the early and blooming periods of vegetation growths are shown in Fig. S2. The analyzed results show that for most areas of arid Asia the values of NDVI during both periods are under 0.6 , and in some extremely arid regions the values $<0.1$, which also varied in different seasons. The DAI in these regions are also usually above 400, which show that there are high intensities of aeolian desertification occurrence on condition that there are climate changes (Fig. S3). However, the analyzed results also show that in the extremely arid areas there are no significant correlations between the NDVI and DAI (Fig. 2), which indicates that the aeolian desertification, might not be significantly controlled by the temperature, precipitation and wind regime scenarios.

Significant negative correlations between the DAI and the NDVI mainly appeared in East and West Asia, and the spatial differences existed. For instances, during the early periods of vegetation growth high correlations appeared in Northeast China, East Mongolia, and some regions of Iran 
and Afghanistan, Turkmenistan, and Kazakhstan, while during the blooming periods of vegetation growth, the main areas with significant negative correlations included Central Asia, Mongolia and some regions of Northeast China. In addition, during the blooming periods of vegetation growths because there were no precipitation in some regions of Iran and Afghanistan, the correlation results between the DAI and NDVI values are absent. The positive correlations between the DAI and NDVI also appeared in Central Asia, some high latitudes, and scattered in the extremely arid regions. The appearance of positive correlations between the DAI and NDVI may be due to the low NDVI values in the season, or be due to the aeolian desertification is not mainly controlled by precipitation, temperature and wind regime. In the alp areas although some significant positive correlations appeared, while previous studies (UNEP, 1992; Gessner et al., 2013; Kraudzun et al., 2014) suggested that there were no high risks of aeolian desertification in these regions.

\subsection{Impacts of temperature on aeolian desertification}

The spatial trends of temperature during the early and blooming periods of vegetation growths are shown in Fig. S4. High temperature during the growing seasons appeared in West and some areas of Central Asia, which is consistent with the correlation results between temperature and NDVI (Fig. 3). The analyzed results show that temperature rise may trigger aeolian desertification in West and Central Asia, and some areas of East Asia, which suggested that the global warming may increase the aeolian desertification of arid Asia. From the early periods of vegetation growth to the blooming periods, the temperature rise benefit the vegetation growth may turn into restrained the vegetation growths in some regions of arid Asia. The restraining effects on vegetation growth decreased from the early periods to blooming periods of vegetation growth in Northeast China and West and Central Asia, while it exhibit an opposite trends in Mongolia. In 
addition, temperature rises play a more important role on aeolian desertification in West and Central Asia and Mongolia than that in the other regions of arid Asia.

\subsection{Impacts of precipitation on aeolian desertification}

For most areas of arid Asia the precipitation during the early and blooming periods of vegetation growths is under $150 \mathrm{~mm}$, and especially in the extremely arid regions are usually under $50 \mathrm{~mm}$ (Fig. S5). During the growing seasons the significant positive correlations between the precipitation and NDVI mainly appeared in regions with precipitation are beyond $75 \mathrm{~mm}$ in the region (Fig. 4). The analyzed results show that the increases of precipitation may restrain the vegetation growths in the extremely arid regions, which its mechanisms are still poorly understood. Regions with significant positive correlations are mainly located in the north and east of Kazakhstan, Mongolia and Northeast China, which shows the precipitation have more close relations on vegetation growths in these regions. In addition, there are some spatial differences for the impacts of precipitation on aeolian desertification. For instances, from the early periods to the blooming periods of vegetation growths, the positive effects of precipitation in Central Asia decreased, while it increased in East Mongolia regions. In most extremely areas, there are no significant correlations between the precipitation and NDVI show that the precipitation may not play important roles on the aeolian desertification in the region.

\subsection{Impacts of wind regime on aeolian desertification}

During the growing season regions with high wind velocity also appeared in the extremely arid areas of Asia (Fig. S6). In some regions of arid Asia, especially in the extremely regions, the analyzed results show that the increase of wind velocity may benefit the vegetation growths (Fig.

5). In West and Central Asia, from the early to the blooming periods of vegetation growths the 
areas with significant negative effects of wind regimes on aeolian desertification increased, while it decreased in East Asia. Compared to the eastern regions, the aeolian desertification in the western arid Asia are more sensitive to increases of wind velocities.

\section{Conclusions}

Although variations in precipitation, temperature and wind regime all exert potential impacts on aeolian desertification in arid Asia, there are spatial differences of aeolian desertification responses on various climate scenarios Significant negative correlations between the DAI and the NDVI shows that aeolian desertification in East and West Asia such as Northeast China, East Mongolia, some regions of Iran and Afghanistan, Turkmenistan, and Kazakhstan are greatly impacted by different climate scenarios. In arid Asia, temperature rise may trigger aeolian desertification in West and Central Asia and Mongolia than that in the other regions. Significant positive correlations between the precipitation and NDVI shows that regions with precipitation are under $75 \mathrm{~mm}$ during the growing seasons are more sensitive to aeolian desertification, and regions with significant positive correlations are mainly located in the north and east of Kazakhstan, Mongolia and Northeast China. From the early periods to the blooming periods of vegetation growths, the effects of precipitation on aeolian desertification in Central Asia decreased, while it increased in East Mongolia regions. In most extremely areas the precipitation may not play important roles on the aeolian desertification. In some regions of arid Asia, especially in the extremely regions, the analyzed results show that the increase of wind velocity may benefit the vegetation growths, while in West and Central Asia, from the early to blooming periods of vegetation growths areas with significant negative effects of wind regimes on aeolian desertification increased, while it decreased in East Asia. Compared to the eastern regions, the 
aeolian desertification in the western arid Asia are more sensitive to increases of wind velocities. Spatial differences of controlling climate scenarios may request the various practices on aeolian desertification combating in arid Asia.

\section{Acknowledgements}

This work was supported by NSFC (Grants No. 41225001).

\section{References}

Ash, J.E., Wasson, R.J., 1983. Vegetation and sand mobility in the Australian desert dunefield. Z. Geomorphol. Suppl. 45, 7-25.

Becker, F., Choudhury, B.J., 1988. Relative sensitivity of normalized difference vegetation index (NDVI) and microwave polarization difference index (MPDI) for vegetation and desertification monitoring. Remote Sens. Environ. 24, 297-311.

Bullard, J.E., Thomas, D.S.G., Livingstone, I., Wiggs, G.F.S., 1997. Dunefield activity and interactions with climatic variability in the southwest Kalahari Desert. Earth Surf. Processes Landforms 22, 165-174.

Conway, D., Schipper, E.L.F., 2011. Adaptation to climate change in Africa. Challenges and opportunities identified from Ethiopia. Global Environ. Change 21, 227-237.

Chen, D., Brutsaert, W., 1998. Satellite-sensed distribution and spatial patterns of vegetation parameters over a tallgrass prairie. J. Atmos. Sci. 55 (7), 1225-1238.

Fang, J., Piao, S., He, J., 2003. Increasing terrestrial vegetation activity in China, 1982-1999. Sci. China C ser. Life Sci. 33, 554-565.

Fensholt, R., Proud, S.R., 2012. Evaluation of earth observation based global long term vegetation trends-comparing GIMMS and MODIS global NDVI time series. Remote Sens. Environ. 119, 131-147.

Gessner, U., Naeimi, V., Klein, I., Kuenzer, C., Klein, K., Dech, S., 2013. The relationship between precipitation anomalies and satellite-derived vegetation activity in Central Asia. Global Planet. Change 110, 74-87.

Hansen, M.C., Stehman, S.V., Potapov, P.V., 2010. Quantification of global gross forest cover loss. Proceed. Natl. Acad. Sci. U.S.A. 107 (19), 8650-8655.

Helldén, U., Tottrup, C., 2008. Regional desertification. A global synthesis. Global Planet. Change 64, 169-176.

Herrmann, S.N., Tappan, G.G., 2013. Vegetation impoverishment despite greening. a case study from central Senegal. J. Arid Environ. 90, 55-66. 
Holben, B.N., 1986. Characteristics of maximum-value composite images from temporal AVHRR data. Int. J. Remote Sens. 7, 1417-1434.

Kraudzun, T., Vanselow, K.A., Samimi, C., 2014. Realities and myths of the Teresken Syndrome - An evaluation of the exploitation of dwarf shrub resources in the Eastern Pamirs of Tajikistan. J. Environ. Manage. 132, 49-59.

Knight, M., Thomas, D.S.G., Wiggs, G.F.S., 2004. Challenges of calculating dunefield mobility over the 21 st century. Geomorphology 59, 197-213.

Lancaster, N., 1988. Development of linear dunes in the southwestern Kalahari, southern Africa. J. Arid Environ. $14,233-244$.

Lancaster, N., Helm, P., 2000. A test of a climatic index of dune mobility using measurements from the southwestern United States. Earth Surf. Proc. Land. 25, 197-207.

Martínez-Graña, A.M., Goy, J.L., Zazo, C., 2015. Cartographic Procedure for the Analysis of Aeolian Erosion Hazard in Natural Parks (Central System, Spain), Land Degrad. \& Dev. 26, 110-117.

McConnell J.R., Aristarain, A.J., Banta, J.R., Edwards, P.R., Simoes, J.C., 2007. $20^{\text {th }}$-Centry doubling in dust archived in an Antarctic Peninsula ice core paralles climate change and desertification in South America. Proceed. Natl. Acad. Sci. U.S.A. 104 (14), 5743-5748.

Mitchell, T.D., Jones, P.D., 2005. An improved method of constructing a database of monthly climate observations and associated high-resolution grids. Int. J. Climatol. 25, 693-712.

Montandon, L.M., Small, E.E., 2008. The impact of soil reflectance on the quantification of the green vegetation fraction from NDVI. Remote Sens. Environ. 112, 1835-1845.

Muhs, D.R., Maat, P.B., 1993. The potential response of eolian sands to greenhouse warming and precipitation reduction on the Great Plains of the U.S.A. J. Arid Environ. 25, 351-361.

Oba, G., Post, E., Stenseth, N.C., 2001. Sub-Saharan desertification and productivity are linked to hemispheric climate variability. Global Change Biol. 7, 241-246.

Piao, S., Fang, J., Liu, H., Zhu, B., 2005. NDVI-indicated decline in desertification in China in the past two decades. Geophys. Res. Lett. 32, L06402 doi.10.1029/2004GL021764.

Piao, S., Wang, X., Ciais, P., Zhu, B., Wang, T., Liu, J., 2011. Changes in satellite-derived vegetation growth trend in temperate and boreal Eurasia from 1982 to 2006. Global Change Biol. 17, 3228-3239.

Pinzon, J.E., Tucker, C.J., 2014. A non-stationary 1981-2012 AVHRR NDVI3g time series. Remote Sens. 6, $6929-6960$. 
Shao, Y., 2008. Physics and Modelling of Wind Erosion. Springer, Berlin.

Shen, M., Piao, S., Jeong, S.J., Zhou, L., Zeng, Z., Ciais, P., Chen, D., Huang, M., Jin, C., Li, Y., Myneni, R.B., Yang, K., Zhang, G., Zhang, Y., Yao, T., 2015. Evaporative cooling over the Tibetan Plateau induced by vegetation growth. Proceed. Natl. Acad. Sci. U.S.A. 112 (30), 9299-9304.

Sheffield, J., Goteti, G., Wood, E.F., 2006. Development of a 50-yr high-resolution global dataset of meteorological forcings for land surface modeling. J. Climate 19 (3), 3088-3111.

Talbot, M. R., 1984. Late Pleistocene rainfall and dune building in the Sahel. Palaeoecol. Africa 16, $203-214$.

Thomas, D.S.G., Knight, M., Wiggs, G.F.S., 2005. Remobilization of southern African desert dune systems by twenty-first century global warming. Nature 435, 1218-1221.

Thomas, D.S.G., Leason, H., 2005. Dunefield activity response to climate variability in the southwest Kalahari. Geomorphology 64, 117-132.

Thornthwaite, C.W., 1948. An approach toward a rational classification of climate. Geogr. Rev., 38, 55-94.

Tsoar, H., 2005. Sand dune mobility and stability in relation to climate. Physica A 357, 50-56.

Tucker, C.J., Dregne, H.E., Newcomb, W.W., 1991. Expansion and contraction of the Sahara Desert from 1980 to 1990. Science 253, 299-301.

Tucker, C.J., Pinzon, J.E., Brown, M.E., Slayback, D.A., Pak, E.W., Mahoney, R., Vermote, E.F., Saleous, N.E., 2005. An extended AVHRR 8-km NDVI dataset compatible with MODIS and SPOT vegetation NDVI data. Int. J. Remote Sens. 26 (20), 4485-4498.

UNEP, 1992. In: Middleton, N., Thomas, D., (Eds.), World atlas of desertification. Edward Arnold, London.

Wang, X., Chen, F., Dong, Z., 2006. The relative role of climatic and human factors in desertification in semi-arid China. Global Environ. Change 16, 48-57.

Wang, X., Chen, F., Hasi, E., Li, J., 2008. Desertification in China. An assessment. Earth-Sci. Rev., 88, 188-206.

Wang, X., Dong, Z., Liu, L., 2004. Sand sea activity and interactions with climatic parameters in the Taklimakan Sand Sea, China. J. Arid Environ. 57, 85-98.

Wang, X., Dong, Z., Zhang, J., Qian, G., 2005. Wind energy environments and dunefield activity in the Chinese deserts. Geomorphology 65, 33-48.

Wang, X., Hasi, E., Zhou, Z., Liu, X., 2007. Significance of variations in the wind energy environment over the past 50 years with respect to dune activity and desertification in arid and semiarid northern China. Geomorphology 86, 252-266.

Wang, X., Yang, Y., Dong, Z., Zhang, C., 2009. Responses of dune activity and desertification in China to global 
warming in the twenty-first century. Global Planet. Change 67, 167-185.

Yizhaq, H., Ashkenazy, Y., Tsoar, H., 2007. Why do active and stabilized dunes coexist under the same climatic conditions? Phys. Rev. Lett. 98, 188001.

Yizhaq, H., Ashkenazy, Y., Tsoar, H., 2009. Sand dune dynamics and climate change. A modeling approach. J. Geophys. Res. Earth Surf. 114 (F1), doi. 10.1029/2008JF001138.

Yehonathan, R., Groner, E., Yizhaq, H., Svoray, T., Bar (Kutiel), P., 2013. An eco-spatial index for evaluating stabilization state of sand dunes. Aeolian Res. 9, 75-87.

Zhang, G., Zhang, Y., Dong, J., Xiao, X., 2013. Green-up dates in the Tibetan Plateau have continuously advanced from 1982 to 2011. Proceed. Natl. Acad. Sci. U.S.A. 110, 4309-4314.

\section{Figure captions}

Fig. 1. Map of the arid Asia and the areas with aeolian desertification risks.

Fig. 2. Significance levels of the Pearson's correlation (2-tailed) between the DAI and NDVI in arid Asia during the early (A) and blooming (B) periods of vegetation growths. Those pixels with positive (negative) correlation coefficients are shown in red (blue).

Fig. 3. Significance levels of the Pearson's correlation (2-tailed) between the temperature and NDVI during the early (A) and blooming (B) periods of vegetation growths. The legends are subject to the plots in Fig. 2.

Fig. 4. Significance levels of the Pearson's correlation (2-tailed) between the precipitation and NDVI during the early (A) and blooming (B) periods of vegetation growths. The legends are subject to the plots in Fig. 2.

Fig. 5. Significance levels of the Pearson's correlation (2-tailed) between the wind regime and NDVI during the early (A) and blooming (B) periods of vegetation growths. The legends are subject to the plots in Fig. 2. 


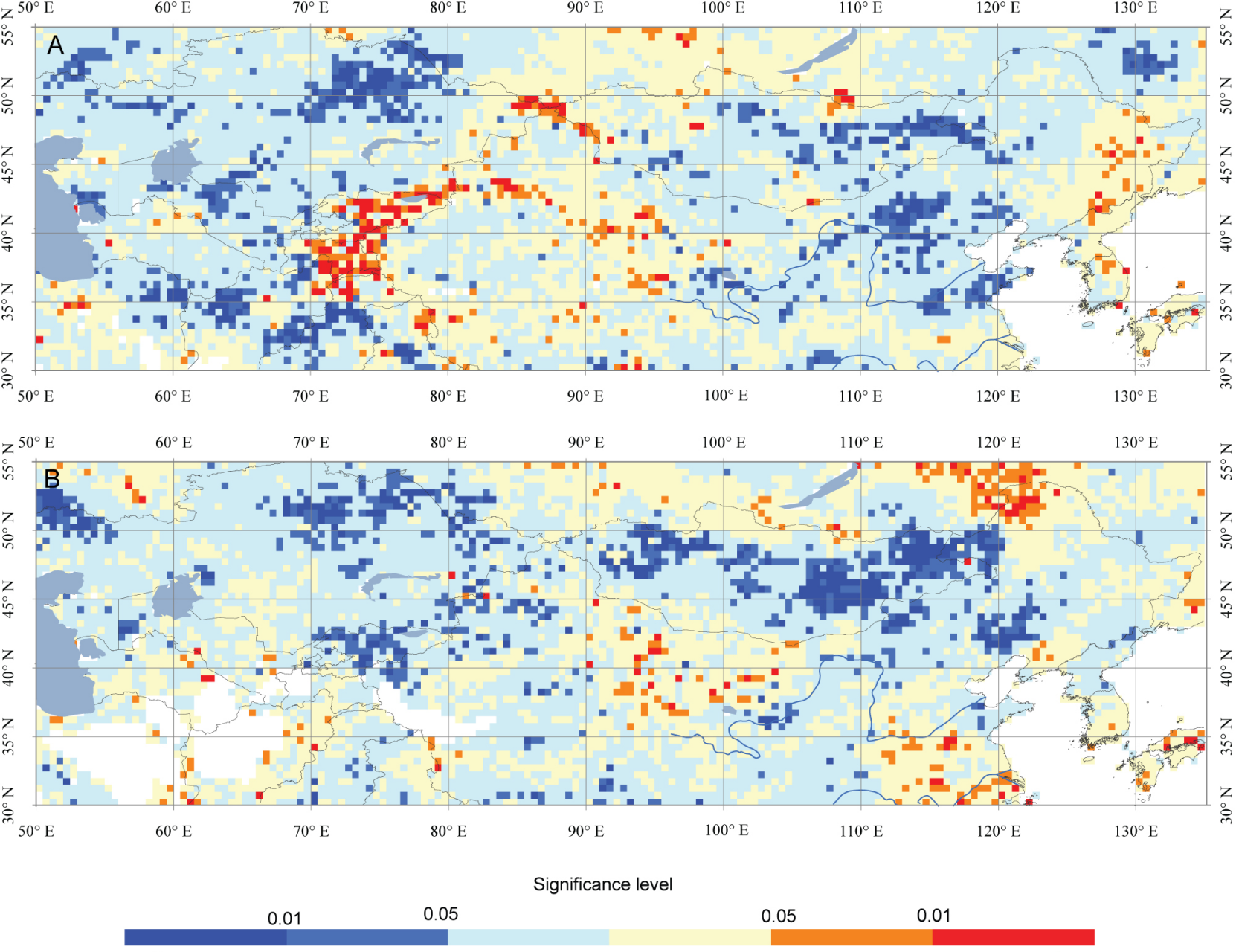




\section{$z^{50^{\circ} \mathrm{E}}$ \\ $80^{\circ} \mathrm{E}$ \\ $90^{\circ} \mathrm{E}$}

$110^{\circ} \mathrm{E}$

$120^{\circ} \mathrm{E}$ 


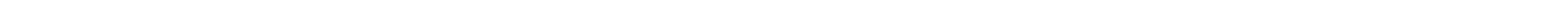




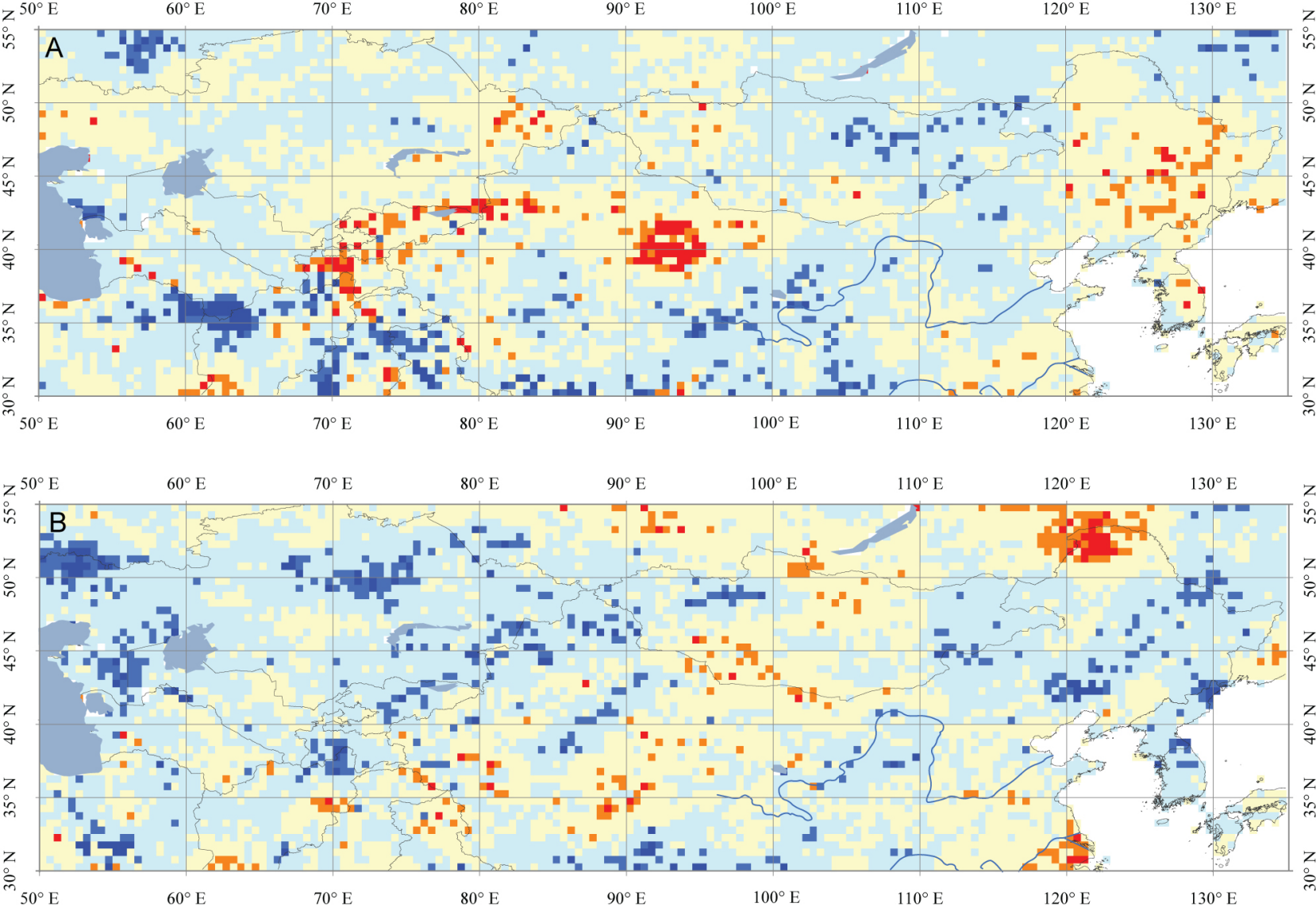


